Article

\title{
Native Roadside Vegetation that Enhances Soil Erosion Control in Boreal Scandinavia
}

Annika K. Jägerbrand ${ }^{1, *}$ and Juha M. Alatalo ${ }^{2}$

1 VTI, The Swedish National Road and Transport Research Institute, Box 55685, 10215 Stockholm, Sweden

2 Department of Ecology and Genetics, Campus Gotland, Uppsala University, SE-621 67 VISBY, Sweden; E-Mail: juha.alatalo@ebc.uu.se

* Author to whom correspondence should be addressed; E-Mail: annika.jagerbrand@vti.se; Tel.: +46-(0)-13-204000; Fax: +46-(0)-13-141436.

Received: 15 May 2014; in revised form: 26 June 2014 / Accepted: 26 June 2014 /

Published: 7 July 2014

\begin{abstract}
This study focused on identifying vegetation characteristics associated with erosion control at nine roadside sites in mid-West Sweden. A number of vegetation characteristics such as cover, diversity, plant functional type, biomass and plant community structure were included. Significant difference in cover between eroded and non-eroded sub-sites was found in evergreen shrubs, total cover, and total above ground biomass. Thus, our results support the use of shrubs in order to stabilize vegetation and minimize erosion along roadsides. However, shrubs are disfavored by several natural and human imposed factors. This could have several impacts on the long-term management of roadsides in boreal regions. By both choosing and applying active management that supports native evergreen shrubs in boreal regions, several positive effects could be achieved along roadsides, such as lower erosion rate and secured long-term vegetation cover. This could also lead to lower costs for roadside maintenance as lower erosion rates would require less frequent stabilizing treatments and mowing could be kept to a minimum in order not to disfavor shrubs.
\end{abstract}

Keywords: erosion resistance; evergreen shrubs; maintenance; native species; roadside; vegetation 


\section{Introduction}

Roadsides are unique manmade environments that are located in the zone between the road surface and the adjacent landscape. They serve several functions for humans, e.g., providing a security zone both in terms of enhancing traffic visibility and for vehicles going off the road and also play an important role for the control of soil erosion and slope stabilization [1]. Simultaneously, roadsides are stressful areas for biological organisms due to, e.g., unusually high concentrations of heavy metals, salt, organic molecules, and nutrients [2].

Vegetation can protect soils from rainfall and wind erosion [1], provide shear root strength and root reinforcement (e.g., [3]) to enhance slope stabilization, reduce surface water run-off, and risks of both shallow and deep landslides [4], and roadside vegetation may also purify polluted runoff from roads [2]. However, road maintenance strategies often fail to incorporate goals and management plans that secure long-term vegetation cover in the roadsides. This is evident by the lack of studies on how to select local native plants for a self-sustaining vegetation cover [5]. Instead, seeding with fast growing (non-native) annual grasses is often used to control erosion of newly constructed roadsides [6].

A sustainable vegetation cover provides a natural and ecological bioengineering protection $[7,8]$ that can increase erosion resistance. Increased erosion resistance is important in stressful roadside habitats susceptible for invasion of alien species, but also since erosion is likely to increase with increased amount of precipitation and occurrences of more extreme weather events. Complex relationships between ecosystem functions (e.g., erosion control) and vegetation characteristics such as cover, biodiversity, biomass, and functional/structural differences make it difficult to predict what form of roadside management that would be most optimal for reducing the impact from, e.g., climate change (cf. [9]).

Furthermore, since roadside environments exhibit special characteristics such as maintenance impact (e.g., [10]), and increased stress and pollution, it is not clear if conclusions arrived from studies on natural and cultural ecosystems can be directly applied on roadside environments (see discussion in [1]). Currently, little attention has been given to what kind of characteristics of the native vegetation in the roadside would be optimal for erosion control. However, such information is important in order to develop management plans that may support a sustainable vegetation cover at roadsides.

This study focused on identifying vegetation characteristics associated with erosion at nine roadside sites in mid-west Sweden. Each site had similar within-site environmental conditions but experienced different levels of erosion so it was possible to compare vegetation characteristics between sub-sites, i.e., eroded versus non-eroded. The vegetation characteristics (i.e., cover, diversity, biomass, and plant community structure) included in this study have been shown or indicated to be correlated with erosion $[9,11-13]$.

\section{Site Descriptions}

The study was conducted in the province of Värmland in mid-West Sweden. During 1961-1990 the mean annual temperature in the province was around $2-5{ }^{\circ} \mathrm{C}$ and annual precipitation between 600-900 $\mathrm{mm}$ [14]. The province belongs to the boreonemoral zone of Fennoscandia and is geologically situated on the Transscandinavian igneous belt and the southwestern gneiss province. Värmland have 
many areas that consist of glaciofluvial deposits of silt, sand, clay, and moraine. Areas predominated by silt and sand are especially vulnerable for erosion. Due to the vulnerability of erosion, it is common in this area that technical measures have been taken to prevent erosion or landslide along roads by the Swedish Road Administration, but not at the sites included in this study. The study sites were constructed when building the roads. The sites are situated along several roads in Northern Värmland. They have not received any revegetation management, but have been left for natural revegetation as is common for smaller roads in Sweden. Road age varies but roads are generally older than 15-30 years or more, therefore, age should not significantly affect results in vegetation succession since this is considered a very long time. Succession processes in boreal areas normally takes place over a few months or years.

\section{Sampling and Analysis}

Nine roadside sites (Table 1) were chosen for the study and vegetation assessments were performed during 21-24 September 2009. At each site, two sub-sites of eroded or non-eroded conditions were identified. Eroded areas experience losses of both soil and vegetation, so it was important to choose eroded sub-sites that had a continuous vegetation cover but were situated under conditions where erosion would be likely to occur. Sub-sites with erosion often had adjacent $(<1 \mathrm{~m})$ patches of exposed soil at the side of the transect (in order to ensure no silting from the eroded spots affected the results) but a relatively high continuous vegetation cover. Eroded sub-sites was judged to be under high risk of future erosion because of nearby patches of exposed soil and/or presence of small rills. The sub-sites without erosion did not have any visible nearby (larger) patches of exposed soil and they did not show any other signs of erosion and seemed resilient against future erosion. The two types of sub-sites were usually within $20 \mathrm{~m}$ distance from each other.

Table 1. Site numbers, coordinates (GPS), and surrounding vegetation classification in accordance with Nordic Council of Ministers [15].

\begin{tabular}{|c|c|c|}
\hline Site No. & Site Coordinates & Surrounding Vegetation Type \\
\hline 1 & N59 $58^{\prime} \mathrm{E} 12^{\circ} 53^{\prime}$ & Pine forest of cowberry (Vaccinium vitis-idaea) type \\
\hline 2 & $\mathrm{~N} 59^{\circ} 55^{\prime} \mathrm{E} 12^{\circ} 50^{\prime}$ & Spruce forest of bilberry (Vaccinium myrtillus) type \\
\hline 3 & $\mathrm{~N} 60^{\circ} 16^{\prime} \mathrm{E} 12^{\circ} 42^{\prime}$ & Pine forest of cowberry (Vaccinium vitis-idaea) type \\
\hline 4 & $\mathrm{~N} 60^{\circ} 08^{\prime} \mathrm{E} 12^{\circ} 57^{\prime}$ & Pine forest of cowberry (Vaccinium vitis-idaea) type \\
\hline 5 & $\mathrm{~N} 59^{\circ} 92^{\prime} \mathrm{E} 13^{\circ} 67^{\prime}$ & Pine forest of cowberry (Vaccinium vitis-idaea) type \\
\hline 6 & $\mathrm{~N} 59^{\circ} 55^{\prime} \mathrm{E} 13^{\circ} 40^{\prime}$ & Pine forest of cowberry (Vaccinium vitis-idaea) type \\
\hline 7 & $\mathrm{~N} 59^{\circ} 52^{\prime} \mathrm{E} 13^{\circ} 43^{\prime}$ & Pine forest of cowberry (Vaccinium vitis-idaea) type \\
\hline 8 & $\mathrm{~N} 59^{\circ} 58^{\prime} \mathrm{E} 12^{\circ} 53^{\prime}$ & Pine forest of cowberry (Vaccinium vitis-idaea) type \\
\hline 9 & $\mathrm{~N} 59^{\circ} 55^{\prime} \mathrm{E} 12^{\circ} 50^{\prime}$ & Spruce forest of bilberry (Vaccinium myrtillus) type \\
\hline
\end{tabular}

At each sub-site, a $1 \mathrm{~m}$ long yardstick was placed parallel with the road direction in the back slope in order to minimize ecological difference from the microhabitats in the ditch and the adjacent natural ecosystems (Figure 1). The distance to the road pavement or the ditch from the sub-sites analysis area was kept the same (approximately $4-6 \mathrm{~m}$ ) between sub-sites within a site so that the ecological variation between sub-sites was kept at a minimum. The slope angle of all back slopes was approximately 
similar (slope angle of $1: 3$, i.e., $18.4^{\circ}$ ) due to construction regulations [16]. For road sections with a higher risk of erosion or landslide angles of 1:4 or 1:5 are recommended in the side- and backslopes, but this did not apply to the study sites in this study.

Figure 1. Cross-section of the road and the road environment, including the location of measurement. Adapted from Karim and Mallik [5].

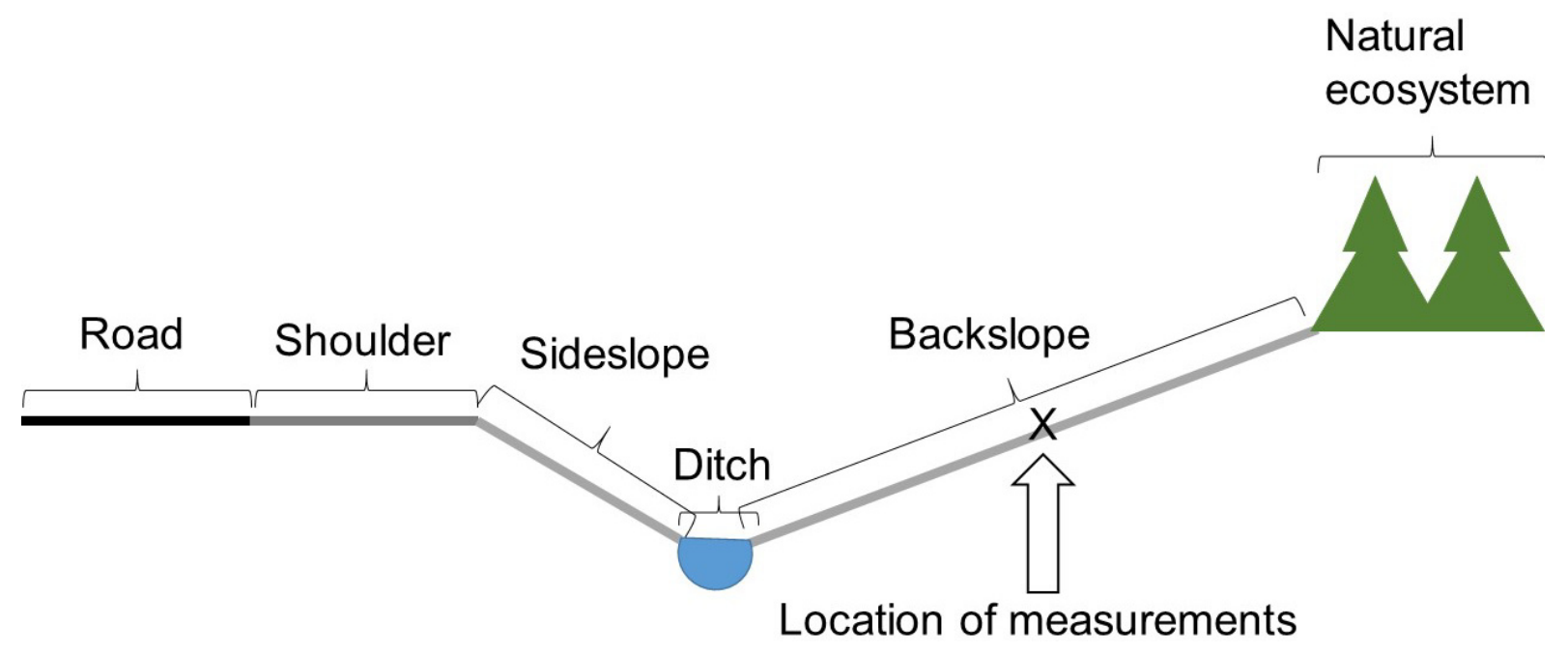

Vegetation assessment was carried out by the point intercept method, using a systematic method of recording hits of species along $1 \mathrm{~m}$ transects at each subsite. The point intercept method records hits of plant species along a line or transects and is commonly used in plant ecology to analyze cover, percentage and species composition. Along each $1 \mathrm{~m}$ transect, species composition and species abundances of vascular plants, bryophytes, and lichens were analyzed at each $1 \mathrm{~cm}$ interval, yielding a measure of relative abundance for each species. In total, 1800 points of species occurrences was measured with the intercept method. This sample size was considered large enough to include species that were important for erosion control. Further, a metal cylinder with an area of $40 \mathrm{~cm}^{2}$ was used to collect five biomass samples evenly along each transects. Biomass samples dried at $70{ }^{\circ} \mathrm{C}$ for $72 \mathrm{~h}$ prior to weighing.

The following plant functional types were used: trees, evergreen shrubs, graminoids (including both grasses and sedges), forbs (i.e., herbaceaous plants, including seedless vascular plants, bryophytes (i.e., liverworts, mosses, and Sphagnum), and lichens. Species nomenclature followed [17] for vascular plants, [18] for bryophytes and liverworts, and [19] for lichens.

\section{Data Analysis}

Due to uneven frequency distribution between roadside sites, data failed to meet the assumptions of normality and homogeneity of variances tested by Shapiro-Wilks and Levenes statistical tests. Thus, the differences between sub-sites with and without erosion were analyszed by pairwise Wilcoxon signed rank test, using SPSS v. 17.0.0 statistical package.

Percentage cover was calculated for each functional group (i.e., trees, evergreen shrubs, graminoids, forbs, bryophytes, and lichens). For a detailed list of species and plant functional groups see Table 2. 
Table 2. Species and plant functional groups at roadsides in Värmland County, Sweden.

\begin{tabular}{|c|c|}
\hline Species & Plant Functional Group \\
\hline Agrostis capillaris $\mathrm{L}$. & Graminoid \\
\hline Betula pendula Roth & Tree \\
\hline Calluna vulgaris (L.) Hull & Evergreen shrub \\
\hline Carex hirta L. & Graminoid \\
\hline Ceratodon purpureus (Hedw.) Brid. & Bryophyte \\
\hline Cetraria islandica (L.) Ach. & Lichen \\
\hline Cladonia arbuscula (Wallr.) Flot. & Lichen \\
\hline Cladonia ciliata Stirt. & Lichen \\
\hline Cladonia rangiferina (L.) Weber ex F.H.Wigg. & Lichen \\
\hline Cladonia stellaris (Opiz) Pouzar \& Vezda & Lichen \\
\hline Cladonia coniocraea (Flörke) Spreng. & Lichen \\
\hline Cladonia crispata (Ach.) Flot. & Lichen \\
\hline Cladonia fimbriata (L.) Fr. & Lichen \\
\hline Cladonia subulata (L.) Weber ex F.H.Wigg. & Lichen \\
\hline Deschampsia flexuosa (L.) Trin. & Graminoid \\
\hline Dicranum polysetum Sw. ex anon. & Bryophyte \\
\hline Dicranum scoparium Hedw. & Bryophyte \\
\hline Empetrum nigrum $\mathrm{L}$. & Evergreen shrub \\
\hline Hylocomium splendens (Hedw.) Schimp. & Bryophyte \\
\hline Juncus compressus Jacq. & Graminoid \\
\hline Jungermannia gracillima $\mathrm{Sm}$. & Lichen \\
\hline Linnaea borealis L. & Forb \\
\hline Lupinus polyphyllus Lindl. & Forb \\
\hline Lycopodium clavatum $\mathrm{L}$. & Forb \\
\hline Peltigera horizontalis (Huds.) Baumg. & Lichen \\
\hline Picea abies (L.) H. Karst & Tree \\
\hline Pinus sylvestris L. & Tree \\
\hline Pleurozium schreberi (Willd. ex Brid.) Mitt. & Bryophyte \\
\hline Pogonatum urnigerum (Hedw.) P.Beauv. & Bryophyte \\
\hline Polytrichastrum formosum (Hedw.) G.L.Sm. & Bryophyte \\
\hline Polytrichum juniperinum Hedw. & Bryophyte \\
\hline Polytrichum piliferum Hedw. & Bryophyte \\
\hline Rhytidiadelphus squarrosus (Hedw.) Warnst. & Bryophyte \\
\hline Solidago virgaurea $\mathrm{L}$. & Forb \\
\hline Sphagnum fallax (H.Klinggr.) H.Klinggr. & Bryophyte \\
\hline Tortula truncata (Hedw.) Mitt. & Bryophyte \\
\hline Vaccinium vitis-idaea $\mathrm{L}$. & Evergreen shrub \\
\hline
\end{tabular}

Biodiversity was analyzed by Simpson's diversity index D [20] and Brillouin's based evenness measure [21] was included as a measure of relative diversity of species.

Plant community structure was analyzed by PCA (principal component analysis) to reveal if the plant species composition differed between eroded and non-eroded sites. PCA was conducted on co-variances, species were centered and standardized, and the PCA was performed in CANOCO 4.5 [22]. 


\section{Results}

There was significant greater cover of evergreen shrubs $(p=0.027)$, total cover $(p=0.011)$, and biomass $(p<0.0001)$ in the non-eroded sites compared to sites with erosion (Table 3$)$. There were no significant differences found in the cover of other functional groups, the number of species, or in the diversity (Table 3). The PCA axis 1 and 2 explained $24.9 \%$ and $15.8 \%$, respectively (Table 4, Figure 2) of the plant species variation, and showed that the plant community structure was not very different between eroded and non-eroded sites. The sites 2, 3, and 5 seems to be separated in plant composition and are scattered towards the right in Figure 2.

Table 3. Mean values ( \pm 1 S.E.) for percentage of cover, number of species, biomass, diversity index and evenness index in eroded and non-eroded sites analyzed by pairwise Wilcoxon signed rank test, n.s. = non-significant.

\begin{tabular}{lccc}
\hline Variable & Eroded & Non-Eroded & $\boldsymbol{p}$ \\
\hline Cover & & & \\
\hline Trees & $3.4( \pm 2.5)$ & $8.3( \pm 3.5)$ & n.s. \\
Evergreen shrubs & $4.3( \pm 3.0)$ & $25.2( \pm 9.7)$ & 0.027 \\
Graminoids & $10.4( \pm 4.1)$ & $20.4( \pm 8.5)$ & n.s. \\
Forbs & $1.7( \pm 1.7)$ & $3.6( \pm 3.6)$ & n.s. \\
Bryophytes & $60.7( \pm 22.1)$ & $72.7( \pm 22.1)$ & n.s. \\
Lichens & $19.1( \pm 8.7)$ & $33.7( \pm 11.8)$ & n.s. \\
Total & $99.7( \pm 24.3)$ & $163.9( \pm 24.8)$ & 0.011 \\
\hline Number of species & & & \\
\hline Trees & $0.4( \pm 0.18)$ & $0.9( \pm 0.26)$ & \\
Evergreen shrubs & $0.3( \pm 0.17)$ & $0.8( \pm 0.22)$ & \\
Graminoids & $1.1( \pm 0.35)$ & $1.2( \pm 0.32)$ & \\
Forbs & $0.1( \pm 0.11)$ & $0.4( \pm 0.44)$ & \\
Bryophytes & $2.6( \pm 0.88)$ & $2.8( \pm 0.66)$ & \\
Lichens & $1.7( \pm 0.47)$ & $1.6( \pm 0.50)$ & \\
Total & $6.2( \pm 1.10)$ & $7.7( \pm 1.01)$ & n.s. \\
\hline Biomass $\left(\mathrm{kg} / \mathrm{m}^{2}\right)$ & $2.4( \pm 0.35)$ & $4.3( \pm 0.42)$ & $<0.0001$ \\
Simpsons diversity index & $0.5( \pm 0.07)$ & $0.7( \pm 0.03)$ & n.s. \\
Brillouins evenness index & $0.4( \pm 0.07)$ & $0.6( \pm 0.04)$ & n.s. \\
\hline
\end{tabular}

Table 4. Results of PCA (principal component analysis) for species composition of eroded and non-eroded sites at roadsites in Värmland County, Sweden.

\begin{tabular}{lccccc}
\hline \multirow{2}{*}{ Eigenvalues and Partitioning of Variance } & \multicolumn{4}{c}{ Axes } & \multicolumn{3}{c}{ Total Variance } \\
\cline { 2 - 6 } & $\mathbf{1}$ & $\mathbf{2}$ & $\mathbf{3}$ & $\mathbf{4}$ & \\
\hline Eigenvalues & 0.249 & 0.158 & 0.131 & 0.118 & 1.000 \\
Cumulative percentage variance of species data & 24.9 & 40.7 & 53.8 & 65.6 & \\
Sum of all eigenvalues & & & & & 1.000 \\
\hline
\end{tabular}


Figure 2. PCA (principal component analysis) of eroded (filled circles) and non-eroded (empty circles) sites at roadsides at Värmland County, Sweden, showing sites. PCA1 explains $24.9 \%$ of the variation, and PCA2 explains $15.8 \%$ of the variation (a total of $40.7 \%$ ). Species abbreviations consist of first three letters in the genus and species name (see Table 2).

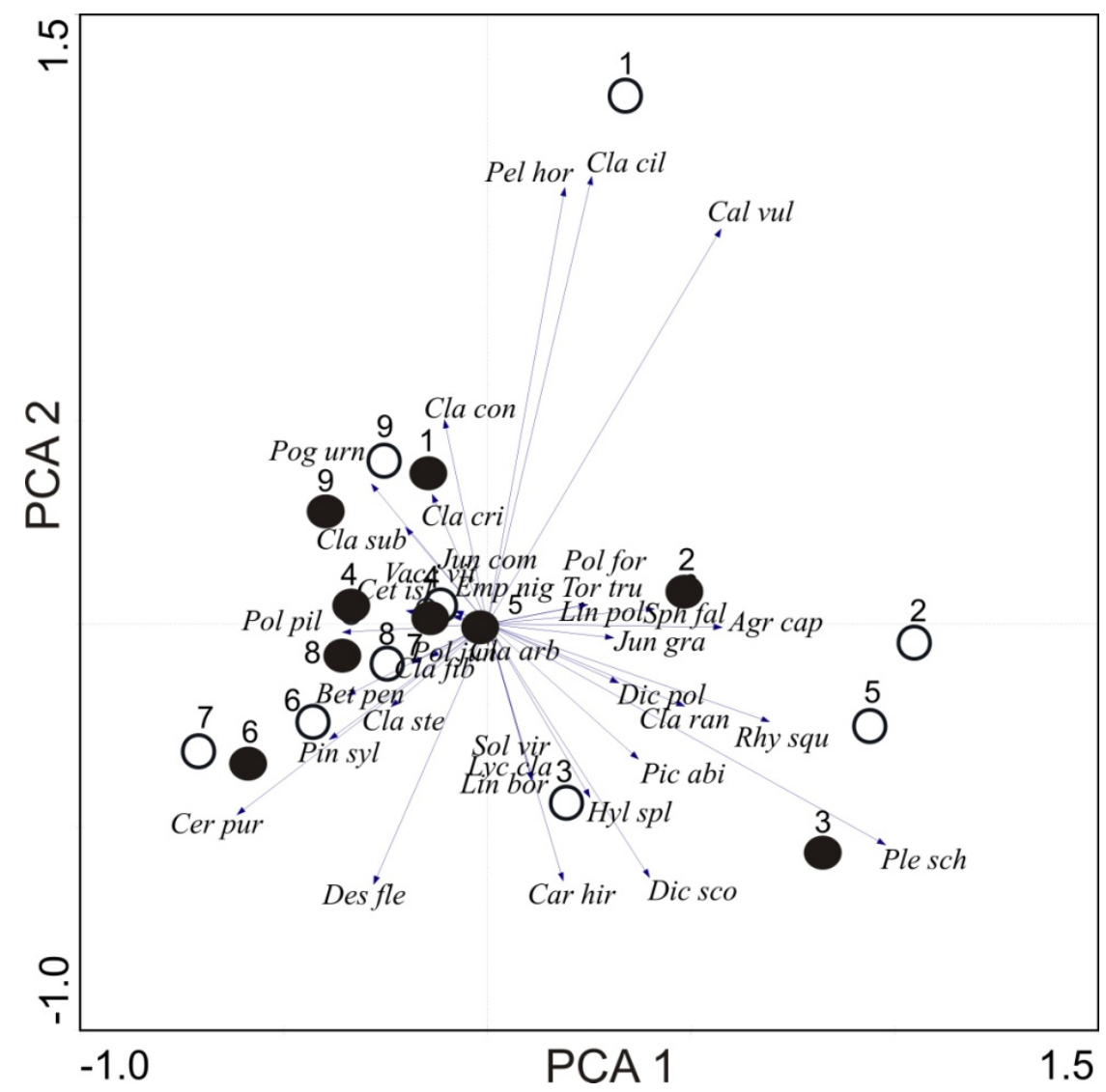

\section{Discussion}

This study shows significant differences in cover between eroded and non-eroded sub-sites in evergreen shrubs and the total cover of all plant functional groups, and significant differences for total above ground biomass between eroded and non-eroded sites. As above ground biomass is closely related to cover, height of plant cover and growth form, it is natural that the non-eroded sub-sites were also found to have higher above ground biomass. We did not see any significant difference between the plant communities between eroded and non-eroded sites.

These results are in line with a significant number of studies showing that erosion will decrease when vegetation cover increases in a range of various vegetation types [23]. Since grasses are fast-growing and used to manage erosion in road areas identified to be vulnerable, we expected the relationship between cover of grasses and erosion to be visible in our study. However, we found no such effects of grasses between eroded and non-eroded sites but instead a significant higher cover of evergreen shrubs in non-eroded sites. Unfortunately, there are few previous studies focusing on vegetation and erosion in boreal zones, probably because erosion is not traditionally seen as a large problem in forest ecosystems. This makes it difficult to compare our results with other studies. 
Nevertheless, the results indicates that the below ground biomass or characteristics in these sites are important to combat erosion. Generally, shrubs have a more deep-root system than compared with that of herbaceaous plants [24]. Karim and Mallik [5] found that shrubs had greater root spreading systems than herbs and that Empetrum nigrum (L.) reached a depth of 15-25 cm. Even so, it is not evident from the literature, which it is evergreen dwarf shrubs or graminoids that develop the most erosion-resistant root systems. For example, Aerts et al. [25] found that the grass Deschampsia flexuosa (L.) Trin. had a root biomass production of 180 compared to $160\left(\mathrm{~g} \cdot \mathrm{m}^{-2} \cdot \mathrm{yr}^{-1}\right)$ that was found for the evergreen dwarf shrub Calluna vulgaris (L.) Hull. Grasslands typically have much higher annual turnover of their root systems than shrublands [26]. Additionally, roots have several other traits that are of importance for erosion susceptibility, e.g., root density, root length density, and mean root diameter [27]. Nonetheless, a more extensive and stable root system will increase soil erosion resistance, and from that perspective, evergreen shrubs may have advantageous over graminoids. In addition, the combination of grasses and evergreen shrubs will produce a mixture of erosion-resistance root systems and may be even more advantageous.

Our results indicate that shrubs can be useful to stabilize vegetation and minimize erosion along roadsides and is supported by results from a study on effects of vegetation on runoff from simulations of rainfall showing that grasses and shrubs in combination protected better against runoff and soil detachment rates compared with grasses per se or natural restoration [28]. However, shrubs are disfavored by several natural and human imposed factors, and is anteceded by grasses and forbs in the natural plant succession order. Other functional plant groups, such as graminoids and forbs, tend to spread faster into disturbed areas, as does active management with seeding of graminoids and mowing frequently used to maintain visibility $[1,10]$.

This could have several impacts on the long-term management of roadsides in boreal regions. By both choosing and applying active management that supports native evergreen shrubs, such as Vaccinium vitis-idaea (L.), Calluna vulgaris (L.) Hull, and Empetrum nigrum L., that typically do not grow to extensive heights in boreal Scandinavia, several positive effects could be achieved along roadsides such as lower erosion rate, and secured long-term vegetation cover. Further, a roadside vegetation dominated by shrubs and other low-growing species will probably obstruct seedling establishment and spread of more late successional species such as trees and high-growing bushes.

This could also lead to lower costs for roadside maintenance as lower erosion rates would require less frequent stabilizing treatments of the roadsides and mowing could be kept to a minimum in order not to disfavor low-growing shrubs [10], simultaneously as reducing the costly need for regular clearance of high-growing shrubs and trees. Karim and Mallik [5] suggested that active large-scale re-vegetation programs with vegetative propagation of shrubs, such as Empetrum nigrum L. and Vaccinium angustifolium (Aiton), are viable alternatives for a sustainable vegetation cover since they have traits that reduce soil erosion, ensure traffic viability and regenerate naturally in boreal Canada. Our results can be seen as supporting Karim and Malliks [5] conclusions on active re-vegetation as we found that low-growing evergreen shrubs enhances soil erosion control. However, in order to develop a more general, or national, management, and maintenance strategy for long-term erosion resistant and natural vegetation for roadside areas, there is need for further research on recommending suitable species of low-growing shrubs for different types of phytogeographical zones in Scandinavia. 


\section{Conclusions}

This study showed that the only functional plant group that had significantly higher plant cover in non-eroded roadsides in comparison with eroded sites, in mid-West Sweden was low-growing evergreen shrubs. The abundance of graminoids and forbs that are commonly used for stabilizing roadsides from erosion did not significantly differ between eroded and non-eroded sites. Thus, our results support the use of low-growing shrubs in order to stabilize vegetation and minimize erosion along roadsides. Management measures that support native evergreen shrubs in boreal regions could achieve several positive effects, such as lower erosion rates, secured long-term vegetation cover, and lower maintenance costs.

\section{Acknowledgments}

Göran Blomqvist, Kent Enkell, Staffan Dahlberg and Elin Jägerbrand are gratefully acknowledged for valuable help. This project was funded by the Swedish National Road and Transport Research Institute (Dnr 2009/0183-24 and project number 12909) and Gotland University.

\section{Author Contributions}

Annika Jägerbrand initiated the project, conducted the fieldwork, species determination, diversity calculations, data analysis, and written the manuscript. Juha Alatalo contributed in writing the manuscript. All authors critically revised the manuscript for intellectual content and approved the final manuscript.

\section{Conflicts of Interest}

The authors declare no conflict of interest.

\section{References}

1. Forman, R.T.T.; Sperling, D.; Bissonette, J.A.; Clevenger, A.P.; Cutshall, C.D.; Dale, V.H.; Fahrig, L.; France, R.B.; Goldman, C.R.; Heanue, K.; et al. Road Ecology: Science and Solutions, 1st ed.; Island Press: Washington, DC/Covelo, CA, USA; London, UK, 2003.

2. Forman, R.T.T.; Alexander, I.J. Roads and their major ecological effects. Annu. Rev. Ecol. Syst. 1998, 8, 629-644.

3. Fan, C.-C.; Su, C.-F. Role of roots in the shear strength of root-reinforced soils with high moisture content. Ecol. Eng. 2008, 33, 157-166.

4. Cazzuffi, D.; Crippa, E. Contribution of vegetation to slope stability: An overview of experimental studies carried out on different types of plans. Geotech. Spec. Publ. 2005, 130-142, 1617-1628.

5. Karim, M.N.; Mallik, A.U. Roadside revegetation by native plants-I. Roadside microhabitats, floristic zonation and species traits. Ecol. Eng. 2008, 32, 222-237.

6. Andres, E.; Jorba, M. Mitigation strategies in some motorway embankments (Catalonia, Spain). Restor. Ecol. 2000, 8, 268-275. 
7. Norris, J.E.; Stokes, A.; Mickovski, S.B.; Cammeraat, E.; van Beek, L.P.H.; Nicoll, B.; Achim, A. Slope Stability and Erosion Control: Ecotechnological Solutions; Springer: Dordrecht, The Netherlands, 2008.

8. Stokes, A.; Atger, C.; Bengough, A.G.; Fourcaud, T.; Sidle, R.C. Desirable plant root traits for protecting natural and engineered slopes against landslides. Plant Soil 2009, 324, 1-30.

9. García-Fayos, P.; Bochet, E. Indication of antagonistic interaction between climate change and erosion on plant species richness and soil properties in semiarid Mediterranean ecosystems. Glob. Chang. Biol. 2009, 15, 306-318.

10. Parr, T.W.; Way, J.M. Management of roadside vegetation-The long-term effects of cutting. J. Appl. Ecol. 1988, 25, 1073-1087.

11. Cyr, L.; Bonn, F.; Pesant, A. Vegetation indices derived from remote sensing for an estimation of soil protection against water erosion. Ecol. Model. 1995, 79, 277-285.

12. Pimentel, D.; Kounang, N. Ecology of soil erosion in ecosystems. Ecosystems 1998, 1, 416-426.

13. Genet, M.; Stokes, A.; Fourcaud, T.; Norris, J.E. The influence of plant diversity on slope stability in a moist evergreen deciduous forest. Ecol. Eng. 2010, 36, 265-275.

14. Klimatdata (Climate Data). Available online: http://www.smhi.se (accessed on 9 December 2012).

15. Nordic Council of Ministers. Vegetation Types of the Nordic Countries; Nordisk Ministerråd, TemaNord 1998:510: Copenhagen, Denmark, 1998; p. 708.

16. The Swedish Transport Administration. Krav för Vägars och Gators Utformning; Report No. 179; The Swedish Transport Administration: Borlänge, Sweden, 2012.

17. Den Virtuella Floran. Available online: http://linnaeus.nrm.se/flora/welcome.html (accessed on 13 May 2014).

18. Ekologisk katalog över Mossor (Onlineversion). Hallingbäck, T., Ed.; ArtDatabanken, SLU: Uppsala, Sweden. Available online: http://www-umea.slu.se/miljodata/webrod/ekkatsv/moss1.asp (accessed on 13 May 2014).

19. Dyntaxa. Svensk Taxonomisk Databas. 2013. Available online: http://www.dyntaxa.se (accessed on 13 May 2014).

20. Simpson, E.H. Measurement of diversity. Nature 1949, 163, 688, doi:10.1038/163688a0.

21. Zar, J.H. Biostatistical Analysis, 3rd ed.; Prentice-Hall: Upper Saddle River, NJ, USA, 1996.

22. Ter Braak, C.J.F.; Šmilauer, P. CANOCO Reference Manual and Canodraw for Windows User's Guide: Software for Canonical Community Ordination, Version 4.5; Microcomputer Power: Ithaca, NY, USA, 2002.

23. Zuazo, V.H.D.; Pleguezuelo, C.R.R. Soil-erosion and runoff prevention by plant covers. A review. Agron. Sustain. Dev. 2008, 28, 65-86.

24. Canadell, J.; Jackson, R.B.; Ehleringer, J.R.; Mooney, H.A.; Sala, O.E.; Schulze, E.-D. Maximum rooting depth of vegetation types at the global scale. Oecologia 1996, 108, 583-595.

25. Aerts, R.; Bakker, C.; de Caluwe, H. Root turnover as determinant of the cycling of C, N, and P in a dry heathland ecosystem. Biogeochemistry 1992, 15, 175-190.

26. Gill, R.A.; Jackson, R.B. Global patterns of root turnover for terrestrial ecosystems. New Phytol. 2000, 147, 13-31.

27. De Baets, S.; Poesen, J.; Knapen, A.; Galindo, P. Impact of root architecture on the erosion-reducing potential of roots during concentrated flow. Earth Surf. Process. Landf. 2007, 32, 1323-1345. 
28. Liu, Y.-J.; Wang, T.-W.; Cai, C.-F.; Li, Z.-X.; Cheng, D.-B. Effects of vegetation on runoff generation, sediment yield and soil shear strength on road-side slopes under a simulation rainfall test in the three gorges reservoir area, China. Sci. Total Environ. 2014, 485-486, 93-102.

(C) 2014 by the authors; licensee MDPI, Basel, Switzerland. This article is an open access article distributed under the terms and conditions of the Creative Commons Attribution license (http://creativecommons.org/licenses/by/3.0/). 